\title{
Coccidiosis in farmed silver foxes (Vulpes vulpes) and blue foxes (Alopex lagopus) in Finland: a case report:
}

\author{
Tapio Juokslahti ${ }^{1 *}$, Teija Korhonen², Antti Oksanen ${ }^{3}$ \\ From Parasite infections of domestic animals in the Nordic countries - emerging threats and challenges. \\ The 22nd Symposium of the Nordic Committee for Veterinary Scientific Cooperation (NKVet) \\ Helsinki, Finland. 7-9 September 2008
}

\section{Summary}

Fur animal farming was initiated during the 1890s on Prince Edward Island in Canada. Farmed silver foxes descend from animals caught from the wild on the island. Finnish fur farming increased during the post war period and in mid-1980s, there were about 6000 fur animal farms, mostly located in Southern Ostrobothnia (Fig.), producing about 8 million fur animals yearly. Currently, there are approximately 1300 fur farms and the yearly production in 2007 was about 2 million fox and 2 million mink furs. The global production at the same time was about 7 million fox and 58 million mink furs.

An outbreak of clinical enteric coccidiosis was encountered at a fox farm with silver foxes (Vulpes vulpes) and blue foxes (Alopex lagopus) in intensive farming district of Osthrobothnia in Finland during summer 2008. The breeding animal stock of the farm consists of 1500 silver fox females and 4000 blue fox females. The whelping period of the silver foxes was from April 20 to May 25, and the whelping period of the blue foxes was from ay 5 to June 10 .

The first clinical signs were seen on silver fox whelps at the age of three weeks. The whelps were unthrifty, their stools were watery, and they littered the floors of the wooden whelping boxes. Their fur was moist and clamped. The females also had moist fur coat, which clamped in the cervical and abdominal areas. There was not increased mortality. The morbidity was about $50 \%$, with all the whelps in affected culls showing the symptoms. At this time the females are still nursing their whelps, and the whelps keep themselves mostly inside

'Helsinki University, Faculty of Veterinary Medicine (Docent), Helsinki, Finland Full list of author information is available at the end of the article the whelping boxes. After these first symptoms, all whelps were studied clinically. They showed marked unthriftyness and poor growth. The body size of the animals was significantly smaller than the normal at this age. Affected whelps were submitted to post-mortem examination to Finnish Food Safety Authority Evira laboratory in Seinäjoki. In parasitological flotation test from intestinal contents, coccidian oocysts were detected. Faecal samples were submitted for quantitative parasitological analysis and species identification.

Of the six silver fox whelp faecal samples, coccidian oocysts were found in 4; max 5600 oocysts per gram (opg), and of the four blue fox whelp faeces, oocysts were found in two, max $120 \mathrm{opg}$. Two species of Isospora were found. Oocysts of the first one were 30-37x24-28 $\mu \mathrm{m}$ (mean [n=20] 35.3 (SD 0.9) x 26.2 (SD 0.4) $\mu \mathrm{m}$, and sporocysts measured 15-16x14-15 $\mu$ m (mean [n=20] 15.5 (SD $0.2) \times 14.8$ (SD 0.5). Sporozoites measured within sporocysts within oocysts were about $13 \times 5 \mu \mathrm{m}$ (cannot be measured very accurately). The oocyst surface is colourless, smooth and clear. There is neither Stieda body nor micropyle in the oocyst or sporocyst. No oocyst granule, but sporocyst residuum sometimes present. This species was identified as Isospora canivelocis (Weidman, 1915) Wenyon, 1923. Duszynski et al. [1] consider it possible that this species is identical with Isospora buriatica Yakimoff and Matschoulsky, 1940 in Matschoulsky, 1941 from the Corsac fox and Indian fox, and, more interestingly, with Isospora canis Nemeseri, 1959 from the domestic dog.

The other species oocysts measured 21-26x16-21 $\mu \mathrm{m}$ (mean [ $\mathrm{n}=10] 23.4(\mathrm{SD}=1.2) \times 18.4(\mathrm{SD}=1.0) \mu \mathrm{m}$, and sporocysts measured 11-13x10-13 $\mu \mathrm{m}$ (mean $[\mathrm{n}=10$ ] 12.2 $(\mathrm{SD}=1.0) \times 11.4(\mathrm{SD}=1.0)$. The oocyst of this 
species is slightly smaller but essentially indistinguishable from Isospora ohioensis Dubey, 1975, which was described to be $24 \times 21$ (21-27x19-23) $\mu \mathrm{m}$ in size. Variation in oocyst size can be caused by e.g crowding in heavy infections. Also the infection phase can affect oocyst size.

The animals were treated with oral sulfadiatzine-trimethoprim (ratio 5:1) medication at a dose of $120 \mathrm{~g}$ per ton of semimoist feed for five days, the effect was variable, but the whelps later gained their normal condition and started to gain weight. The treatment was judged to be satisfactory.

A second outbreak was observed on the same farm in blue fox whelps, when they reached the age of three weeks. The symptoms were similar to that of the silver foxes earlier, but more severe. The mortality was low also at this outbreak, but morbidity was higher, and the weight development was more affected. Whelps were submitted to post-mortem examination, and coccidiosis was confirmed. The affected whelps were treated with one individual oral dosing of toltrazuril by syringe at $10 \mathrm{mg}$ per whelp and with oral sulfadiatzine-trimethoprim medication for five days, similar to the silver fox whelps. The recovery in the blue fox outbreak was pronounced, and better than that of the silver fox outbreak.

\section{Discussion}

The whelps most probably received the infection from their dams, which are known to shed parasites at puerperal period. Also horizontal infection within litters in the whelping boxes is to be considered. The hygienic conditions on the farm deserve attention, and on this farm they may have contributed to the outbreak.

The farm is located in the intensive fur farming district with proximity to other fur animal farms. The spread of the parasites within the farm and possibly also between other farms may have been facilitated by blackheaded gulls (Larus ridibundus), which frequently feed under the cage nettings and the feeding boards of the foxes. They may be vectors for the parasite spread with their feet.

Clinical coccidiosis is reported on fur animals [2], clinical case of this severity is the first one encountered in Finland. From the Internet, it appears that in Chinese veterinary medical literature, silver fox coccidiosis is described as a well-known disease and an important problem [3].

This reported outbreak calls for closer examination of the occurrence of clinical coccidiosis amongst Finnish fox farms, the coccidian species capable of infecting both blue foxes and silver foxes, and the control measures of the clinical coccidiosis including potential infection routes, vehicles, and the therapy.

\section{Author details}

${ }^{1}$ Helsinki University, Faculty of Veterinary Medicine (Docent), Helsinki, Finland ${ }^{2}$ Finnish Food safety Authority Evira, Production Animal Health Research Unit, Seinäjoki, Finland. ${ }^{3}$ Finnish Food safety Authority Evira, Fish and Wildlife Health Research Unit (FINPAR), Oulu, Finland.

Published: 13 October 2010

\section{References}

1. Duszynski DW, Couch L, Upton SJ: Coccidia (Eimeriidae) of Canidae and Felidae. Supported by NSF-PEET DEB 95216872000 [http://biology.unm.edu/ biology/coccidia/carniv1.html].

2. Wenzel UD, Berestov VA: Pelztierkrankheiten. VEB Deutscher, Berlin 1986, 98-99.

3. Ping JiXing, Hongyong Wang, Zhou Zhenghong, Zhenchun to: Silver Fox coccidiosis treatment. Cure of the silver fox Coccidiosis. Poujian through pathology and laboratory checks to early diagnosis of the Silver Fox coccidiosis, and to Treatment. Coccidia powder words of the disease have a better effect, in addition, sanitation is also extremely important. Hubei Animal Husbandry and Veterinary 2003, 01.

doi:10.1186/1751-0147-52-S1-S18

Cite this article as: Juokslahti et al:: Coccidiosis in farmed silver foxes (Vulpes vulpes) and blue foxes (Alopex lagopus) in Finland: a case report:. Acta Veterinaria Scandinavica 2010 52(Suppl 1):S18.

\section{Submit your next manuscript to BioMed Central and take full advantage of:}

- Convenient online submission

- Thorough peer review

- No space constraints or color figure charges

- Immediate publication on acceptance

- Inclusion in PubMed, CAS, Scopus and Google Scholar

- Research which is freely available for redistribution

Submit your manuscript at www.biomedcentral.com/submit
C Biomed Central 